\title{
Mortgage Interest Tax Shield and Home Mortgage Refinancing Decision
}

\author{
Sang-Hoon Kim*, Dong-Kyoon Kim \\ Feliciano School of Business, Montclair State University, United States
}

Copyright $(2016$ by authors, all rights reserved. Authors agree that this article remains permanently open access under the terms of the Creative Commons Attribution License 4.0 International License

\begin{abstract}
Under current low interest rates, the decision whether or not to refinance a mortgage is a timely and practically useful topic. However, the home mortgage refinancing decision is also affected by other variables such as personal tax rate. In addition, financial institutions provide different types of mortgage loans in terms of maturity (loan period), interest rate, processing cost, points (bank fee), and so forth. Several websites are available which can be used to aid making the refinancing decision. However, these websites programs are not explicitly geared towards selecting a low cost mortgage loan. Furthermore, these websites are limited in their usefulness due to inadequate assumptions or the difficulty of acquiring information required for the program. For example, a certain website requires information such as the expected future interest rate, the expected inflation rate, the standard deviation of mortgage interest rates, and so forth. To be practically useful, the assumptions should be simple and reasonably realistic. The objective of this paper is to prepare, under realistically reasonable assumptions, an Excel program which can select a low cost mortgage loan after consideration of the tax deductibility of mortgage interest rate. This paper can be used as a case problem for both undergraduate and MBA students. From the case, students learn how Excel (or any spread sheet program) can be programed and used to analyze finance problems.
\end{abstract}

Keywords Mortgage Refinancing Decision, Tax Deductibility, Excel Program

\section{Introduction}

Research papers on mortgage refinancing decision proposed different methods such as the internal rate of return method (Valachi, [6]) and NPV method (Followill and Johnson, [3]). Also scholars used different set of information such as closing costs, old and new mortgage rates, and taxes (G. Yohannes, [7] and Auster, [1]) and proposed different models such as the model proposed by Chen and Ling [2] and Johnson and Randle [5]).
Mortgage loans can be refinanced with a mortgage whose maturity is longer, equal to, or less than the remaining period of the existing mortgage. If the loan period is different, it is not an easy issue to examine the impact of the tax deductibility of mortgage interest payment on refinancing decision because the tax shields are occurring every year over the remaining mortgage period and the tax shields are different between original loan and the new loan due to the different interest rate.

As pointed out by Fortin and Michelson [4], tax impacts of home mortgage loan which is often ignored by investors is a very important component in refinancing decision. The purpose of this case is to prepare an Excel program which can accommodate these three possible refinancing situations and the impact of the tax shield under simple but reasonably realistic assumptions so that users of the Excel program do not need to provide information such as the expected future inflation, and interest rates or the standard deviation of mortgage interest rates. The assumptions made are:

- Cash flows can be reinvested at the new mortgage interest rate.

Just as for the valuation of any financial asset, in order to analyze the refinancing decision, an interest rate at which interim cash flows can be invested and discounted should be provided. However, it is not possible to correctly project future interest rates. Consequently, just as bonds are valued using equivalent bond yields prevailing at the time bond purchase, the new interest rate at which the old mortgage loan is refinanced will be used as the discount rate.

- The amount of the new loan includes not only the existing loan balance and various refinancing costs but also any points.

For reliable analysis, the loan amount should cover all refinancing costs such that no additional cash outflow is required. The appendix shows how to compute the required loan amount.

- Mortgage interest payments are tax deductible and the average personal tax rates remain constant during the loan period. 
The loan will not be paid off until the maturity of the new loan (no prepayment).

This assumption can be changed to accommodate possible early loan payment. The Excel program which can be used to select the most desirable mortgage loan was prepared assuming that the following information is provided:

1) Regarding the original loan:

a. The initial loan amount,

b. The number of month elapsed (total number of monthly mortgage payment already made),

c. The amount of the monthly payment

2) Regarding the new loan:

a. The loan period,

b. The annual mortgage rate

c. Various processing costs, and

d. Points (bank fee) to be paid

3) Personal tax rate of the home owner. It will be assumed that the tax rate remains constant until the loan is paid off.

The following section shows three home mortgage loans along with an original mortgage loan. Following the example, three other sections cover the Excel program, solution, conclusion, and websites related to the refinancing decision.

\section{Methodology}

Example: John Smith bought a house five years ago, with a 30 year $\$ 200,433.89$ home mortgage loan which requires a monthly mortgage payment of $\$ 1,700$. John is considering refinancing the current loan (hereafter "old loan" or "original loan") with one of the three mortgage loans (hereafter "new loans") which have different loan periods of 30,25 , or 15 years respectively. Table 1 shows summary of the three mortgage loans.
Table 1. Summary of three mortgage loans

\begin{tabular}{|c|c|c|c|}
\hline $\begin{array}{c}\text { Mortgage loan } \\
\begin{array}{c}\text { Maturity (loan period) } \\
\text { (year) }\end{array}\end{array}$ & 30 & 25 & 15 \\
\hline $\begin{array}{c}\text { Annual mortgage rate } \\
(\%)\end{array}$ & 6.00 & 5.50 & 5.2 \\
\hline Bank fee (points)(\%) & 2.50 & 0.00 & 1.00 \\
\hline Application fee & $\$ 350$ & $\$ 500$ & $\$ 300$ \\
\hline Appraisal fee & 200 & 200 & 200 \\
\hline Title search & 200 & 200 & 150 \\
\hline Title Exam & 500 & 500 & 400 \\
\hline Survey cost & 400 & 400 & 500 \\
\hline Attorney Fee & 600 & 600 & 500 \\
\hline Credit report & 40 & 100 & 80 \\
\hline Flood Certification & 20 & 40 & 30 \\
\hline Recording fee & 50 & 80 & 60 \\
\hline Pest Inspection & 80 & 100 & 100 \\
\hline Other costs & 400 & 500 & 500 \\
\hline
\end{tabular}

Assuming that John has just paid the $60^{\text {th }}$ monthly mortgage payment and his income tax rate is $30 \%$, this paper provides an Excel program which can be used to derive the following information:

An Excel program was prepared to compute the following:

1) The annual interest rate of the original mortgage loan

2) The current loan balance of the original loan (CLB).

3) The total amount of new loan (NL) which includes the loan processing cost, bank fee, etc.

4) The monthly mortgage payment of the new mortgage loan

5) The difference of the monthly mortgage payments between old and new loans

6) The PV of the total savings from the refinancing before tax shield

7) The effective interest rate of the new mortgage loan

8) PV of total tax shield (benefit or loss)

9) Net Savings from refinancing after the tax shield

10) The Monthly mortgage amortization schedule.

Excel Program: To facilitate solution, the Excel program was prepared using the following solution template. 
Table 2. Excel Solution Template

\begin{tabular}{|c|c|c|c|c|c|c|c|c|c|}
\hline & A & B & $\mathrm{C}$ & $\mathrm{D}$ & $\mathrm{E}$ & $\mathrm{F}$ & G & $\mathrm{H}$ & I \\
\hline 1 & \multirow{6}{*}{$\begin{array}{l}\text { DATA } \\
\text { ENTRY }\end{array}$} & Old Loan & Loan Amount & $\begin{array}{l}\text { Monthly } \\
\text { payment }\end{array}$ & $\begin{array}{l}\text { Maturity } \\
\text { (Year) }\end{array}$ & $\begin{array}{c}\text { No of month } \\
\text { elapsed }\end{array}$ & $\begin{array}{l}\text { Personal } \\
\text { Tax Rate }\end{array}$ & & \\
\hline 2 & & Old Loan & & & & & & & \\
\hline 3 & & New Loan & Point $(\%)$ & $\begin{array}{c}\text { Maturity } \\
\text { (Year) }\end{array}$ & $\begin{array}{c}\text { Interest } \\
\text { Rate } \\
\text { (Year \%) }\end{array}$ & $\begin{array}{l}\text { Application } \\
\text { Fee }\end{array}$ & $\begin{array}{l}\text { Appraisal } \\
\text { Fee }\end{array}$ & Title Search & Title Exam \\
\hline 4 & & New Loan & & & & & & & \\
\hline 5 & & & Survey Cost & $\begin{array}{l}\text { Attorney } \\
\text { Fee }\end{array}$ & $\begin{array}{l}\text { Credit } \\
\text { Report }\end{array}$ & $\begin{array}{c}\text { Flood } \\
\text { Certification }\end{array}$ & $\begin{array}{l}\text { Recording } \\
\text { Fee }\end{array}$ & $\begin{array}{c}\text { Pest } \\
\text { Inspection }\end{array}$ & Other Costs \\
\hline 6 & & & & & & & & & \\
\hline 7 & & & & & & & & & \\
\hline 8 & & & & \multicolumn{5}{|c|}{ Total Processing Cost of New Loan except the Point $=$} & \\
\hline 9 & & Questions & & & & & $\begin{array}{c}\text { Interim } \\
\text { Solutions }\end{array}$ & & \\
\hline 10 & & \multicolumn{4}{|c|}{ The annual interest rate of the old mortgage loan. } & Monthly Rate $=$ & & Annual Rate $=$ & \\
\hline 11 & & \multicolumn{4}{|c|}{ The current loan balance (CLB) of original loan } & & & & \\
\hline 12 & & \multicolumn{4}{|c|}{ The total amount of new loan including all processing cost } & & & & \\
\hline 13 & & \multicolumn{4}{|c|}{ The monthly mortgage payment of the new mortgage loan. } & & & & \\
\hline 14 & & \multicolumn{4}{|c|}{ The difference of the monthly mortgage payments } & & & & \\
\hline 15 & & \multicolumn{4}{|c|}{ The PV of the total savings from the refinancing } & & & & \\
\hline 16 & & \multicolumn{4}{|c|}{$\begin{array}{c}\text { a. PV(Saving) Mortgage } \geq \text { than the remaining period of old } \\
\text { mortgage }\end{array}$} & & & & \\
\hline 17 & & \multicolumn{4}{|c|}{$\begin{aligned} \text { b. PV(Saving)Mortgage } & <\text { than the remaining period of old } \\
& \text { mortgage }\end{aligned}$} & & & & \\
\hline 18 & & \multicolumn{4}{|c|}{ The effective interest rate of the new mortgage loan } & & & & \\
\hline 19 & & \multicolumn{4}{|c|}{ PV of total tax shield (benefit or loss) } & & & & \\
\hline 20 & & \multicolumn{4}{|c|}{ a. PV (total tax shield from the original loan) } & & & & \\
\hline 21 & & \multicolumn{4}{|c|}{ b. PV (total tax shield from the new loan) } & & & & \\
\hline 22 & & \multicolumn{4}{|c|}{ 9. Net savings from refinancing after the tax shield } & & & & \\
\hline 23 & & \multicolumn{4}{|c|}{ 10. The monthly mortgage amortization schedule: } & & & & \\
\hline \multicolumn{10}{|l|}{24} \\
\hline 25 & & \multicolumn{6}{|c|}{ Monthly mortgage amortization schedule } & & \\
\hline 25 & & Month No & $\begin{array}{l}\text { Beginning } \\
\text { Balance }\end{array}$ & $\begin{array}{l}\text { Monthly } \\
\text { Payment }\end{array}$ & $\begin{array}{l}\text { Interest } \\
\text { Payment }\end{array}$ & $\begin{array}{l}\text { Principal } \\
\text { Payment }\end{array}$ & $\begin{array}{l}\text { Ending } \\
\text { Balance }\end{array}$ & PV(Interest) & $\begin{array}{c}\text { Total PV of } \\
\text { Interest PMT }\end{array}$ \\
\hline 26 & & 1 & & & & & & & \\
\hline 27 & & 2 & & & & & & & \\
\hline 28 & & - & & & & & & & \\
\hline 29 & & $\bullet$ & & & & & & & \\
\hline 30 & & - & & & & & & & \\
\hline
\end{tabular}

The template is divided into two areas: the area for information (above line 7: hereafter referred to as the "data entry area") and the area for the Excel program (below line 7: hereafter, the "solution area"). The data entry area is self-explanatory. The light gray colored cells represents for the software program. If the example is used as a case problem, it is necessary to provide students with an Excel template. Otherwise, it is extremely difficult to grade the Excel programs submitted by students. In addition, the finished template makes it easy to evaluate various home loan mortgages. The following table is for the summary of solutions to be obtained from the Excel Program. The solution summary table is convenient if the example is used as a case problem. 
Table 3. Solution Summary

\begin{tabular}{|c|c|c|c|c|c|}
\hline & & \multicolumn{4}{|c|}{ Solution } \\
\hline & Questions & $\begin{array}{c}\text { Old } \\
\text { Mortgage }\end{array}$ & Mortgage A & Mortgage B & Mortgage C \\
\hline 0 & Total processing cost excluding the point & & & & \\
\hline 1 & The annual interest rate of the old mortgage loan. & & & & \\
\hline 2 & The current loan balance (CLB). & & & & \\
\hline 3 & The total amount of new loan (NL) & & & & \\
\hline 4 & Monthly mortgage payment of the new mortgage & & & & \\
\hline 5 & The difference of the monthly mortgage PMT between old \& new loan & & & & \\
\hline 6 & The present value of the total savings from the refinancing & & & & \\
\hline 7 & The effective interest rate of the new mortgage against the old loan & & & & \\
\hline 8 & The PV of total tax shield (benefit or loss) & & & & \\
\hline 9 & Net savings from refinancing after the tax shield & & & & \\
\hline 10 & The monthly mortgage amortization schedule: & & \multicolumn{3}{|c|}{ Not shown because of the size of Table } \\
\hline & Select the mortgage which provides the largest saving & \multicolumn{4}{|c|}{ Mortgage A ( ) Mortgage B ( x ) Mortgage C ( ) } \\
\hline
\end{tabular}

The following table provides Excel program. The (gray) cells of solution template can filled with the equations shown in the second column of the table.

Table 4. Excel Program

\begin{tabular}{|c|c|c|}
\hline $\begin{array}{c}\text { Question } \\
\text { No } \\
\end{array}$ & $\begin{array}{c}\text { Cell } \\
\text { address }\end{array}$ & Equations \\
\hline & I8 & $=\mathrm{SUM}(\mathrm{F} 4: \mathrm{I} 4)+\mathrm{SUM}(\mathrm{C} 6: \mathrm{I} 6) \rightarrow$ Total Processing cost \\
\hline & G10 & $=\mathrm{RATE}(12 * \mathrm{E} 2, \mathrm{D} 2,-\mathrm{C} 2,0) \rightarrow$ Monthly mortgage rate of the original loan. \\
\hline 1 & $\mathrm{I} 10$ & $=\mathrm{G} 10 * 12$ \\
\hline 2 & I11 & $=\mathrm{PV}(\mathrm{G} 10, \mathrm{E} 2 * 12-\mathrm{F} 2,-\mathrm{D} 2,0)$ \\
\hline 3 & $\mathrm{I} 12$ & $=(\mathrm{I} 11+\mathrm{I} 8) /(1-\mathrm{C} 4)$ \\
\hline 4 & $\mathrm{I} 13$ & $=\mathrm{PMT}(\mathrm{E} 4 / 12,12 * \mathrm{D} 4,-\mathrm{I} 12,0)$ \\
\hline 5 & $\mathrm{I} 14$ & $=\mathrm{D} 2-\mathrm{I} 13$ \\
\hline \multirow[t]{3}{*}{6} & $\mathrm{I} 15$ & $=\mathrm{IF}(\mathrm{D} 4 * 12>(\mathrm{E} 2 * 12-\mathrm{F} 2), \mathrm{H} 16, \mathrm{H} 17)$ \\
\hline & H16 & $=((\mathrm{PV}(\mathrm{E} 4 / 12,(\mathrm{E} 2 * 12-\mathrm{F} 2),-\mathrm{I} 14,0)))+\mathrm{IF}((\mathrm{D} 4 * 12=\mathrm{E} 2 * 12-\mathrm{F} 2), 0, \mathrm{PV}(\mathrm{E} 4 / 12,(\mathrm{D} 4 * 12-(\mathrm{E} 2 * 12-\mathrm{F} 2)), 113)(1+\mathrm{E} 4 / 12)(\mathrm{D} 4 * 12-\mathrm{F} 2))$ \\
\hline & H17 & $=\mathrm{PV}(\mathrm{E} 4 / 12, \mathrm{D} 4 * 12,0, \mathrm{PV}(\mathrm{E} 4 / 12, \mathrm{E} 2 * 12-\mathrm{F} 2-\mathrm{D} 4 * 12, \mathrm{D} 2,0))+\mathrm{PV}(\mathrm{E} 4 / 12, \mathrm{D} 4 * 12,-\mathrm{I} 14,0)$ \\
\hline 7 & I18 & $=$ RATE $(\mathrm{D} 4 * 12, \mathrm{I} 13,-\mathrm{I} 11,0) * 12$ \\
\hline \multirow[t]{3}{*}{8} & I19 & $=\mathrm{H} 21-\mathrm{H} 20$ \\
\hline & $\mathrm{H} 20$ & $=\mathrm{Q} 6 * \mathrm{G} 2$ \\
\hline & $\mathrm{H} 21$ & $=\mathrm{I} 27 * \mathrm{G} 2$ \\
\hline 9 & $\mathrm{I} 22$ & $=\mathrm{I} 15+\mathrm{I} 19$ \\
\hline \multicolumn{3}{|l|}{10} \\
\hline & $\mathrm{C} 27$ & $=\mathrm{I} 12$ \\
\hline & D27 & $=\$ I \$ 13$ \\
\hline & E27 & $=\mathrm{C} 27 * \$ E \$ 4 / 12$ \\
\hline & F27 & $=\mathrm{D} 27-\mathrm{E} 27$ \\
\hline & G27 & $=\mathrm{C} 276-\mathrm{F} 27$ \\
\hline & $\mathrm{C} 28$ & $=\mathrm{IF}(\mathrm{G} 27<=0,0, \mathrm{G} 27)$ \\
\hline & D28 & $=\mathrm{IF}(\mathrm{G} 27<=0,0, \$ \mathrm{I} \$ 13)$ \\
\hline & E28 & $=\mathrm{C} 28 * \$ E \$ 4 / 12$ \\
\hline & F28 & $=\mathrm{D} 28-\mathrm{E} 28$ \\
\hline & G28 & $=\mathrm{C} 28-\mathrm{F} 28$ \\
\hline
\end{tabular}

* $2^{\text {nd }}$ question: The loan balance can be found by computing the present value of all remaining monthly mortgage payments.

$* 3^{\text {rd }}$ question: $\mathrm{NL}$ (new loan amount) can be derived such that $\mathrm{NL}=(\mathrm{CLB}+\mathrm{TP}) *(1 /(1-\mathrm{a}))$ where $\mathrm{CLB}=$ current loan balance, $\mathrm{TP}=\mathrm{Total}$ processing cost (not including any points), and $\mathrm{a}=$ the point (as a percentage: if $2 \%$, use .02). For the derivation of the formula, see the appendix.

$* 4^{\text {th }}$ question: The monthly mortgage payment cannot be negative.

$* 6^{\text {th }}$ question: This equation accommodates all refinancing situations with a mortgage loan equal to, less than, or longer than the remaining period of old mortgage.

$* 7^{\text {th }}$ question: Note that the actual mortgage (effective) rate should be higher than the nominal mortgage rate of new loan because of the refinancing cost. $* 8^{\text {th }}$ question: The computation of the PV of total tax shield (benefit or loss) requires to find the present values of each monthly interest payments under both original loan and new loan. Since these computation requires very lengthy monthly mortgage amortization schedule of both original and new loans, this schedules are not shown due to the size of these tables.

$* 10^{\text {th }}$ question: The monthly mortgage amortization table can be completed by copying C28, D28, E28, F28, and G28 into the rest of table. The table for the monthly mortgage amortization schedule is not shown because of the size of the Table.

Using the Excel program, the three mortgage loans are analyzed and the results are shown in table 5. 
Table 5. Solution Summary

\begin{tabular}{|c|c|c|c|c|c|}
\hline & & \multicolumn{4}{|c|}{ Solution } \\
\hline & Questions & Old Mortgage & Mortgage A & Mortgage B & Mortgage $\mathrm{C}$ \\
\hline 0 & Total processing cost excluding the point & & $\$ 2,840.00$ & $\$ 3,220.00$ & $\$ 2,820.00$ \\
\hline 1 & The annual interest rate of the old mortgage loan. & $9.60 \%$ & & & \\
\hline 2 & The current loan balance (CLB). & $\$ 193,037.47$ & & & \\
\hline 3 & The total amount of new loan (NL) & & $\$ 200,899.97$ & $196,257.47$ & $\$ 197,835.83$ \\
\hline 4 & Monthly mortgage payment of the new mortgage & & $\$ 1,204.50$ & $1,205.19$ & $1,585.16$ \\
\hline 5 & The difference of the monthly mortgage PMT between old \& new loan & & $\$ 495.50$ & 494.81 & 114.84 \\
\hline 6 & The present value of the total savings from the refinancing & & $\$ 62,951.70$ & $80,576.04$ & $87,254.84$ \\
\hline 7 & The effective interest rate of the new mortgage against the old loan & & $6.38 \%$ & $5.67 \%$ & $5.58 \%$ \\
\hline 8 & The PV of total tax shield (benefit or loss) & & $\$-5,186.61$ & $-12,514.15$ & $-23,790.60$ \\
\hline 9 & Net savings from refinancing after the tax shield & & $\$ 57,765.09$ & $68,061.89$ & $63,464.24$ \\
\hline 10 & The monthly mortgage amortization schedule: & & \multicolumn{3}{|c|}{ Not shown because of the size of Table } \\
\hline & Select the mortgage which provides the largest saving & \multicolumn{4}{|c|}{ Mortgage A ( ) Mortgage B ( x ) Mortgage C ( ) } \\
\hline
\end{tabular}

Mortgage $B$ provides the largest savings from the refinancing. However, it should be noted that Mortgage 3 provides the largest saving and the lowest effective interest rate, if the tax shield is not considered. Consequently, the tax shield of mortgage interest payment is a very important component in refinancing decision.

\section{Conclusions}

Financial institutions provide different mortgage loans in terms of loan period, mortgage interest rate, processing costs, and bank fees. The use of an Excel program provided makes it possible to compare mortgages with different terms and select the one which provides the largest savings from the refinancing. The example shows that the tax shield of mortgage interest payment is a very important variable which cannot be overlooked in home mortgage refinancing decision. This is due to the different mortgage interest rate between the original and new loans. Furthermore, it should be noted that if mortgage loans are refinanced with a new loan of vastly different loan period, the impact of the tax shield can be significant.

Considering the current low interest rates, the mortgage refinancing decision is a relevant and practically useful case problem for introductory finance and/or finance case courses. Furthermore, it is a very useful case problem to illustrate how Excel program can be used to analyze finance problems.

\section{Appendix}

\section{Derivation of a formula for new loan amount}

Let CLB $=$ Current loan balance

$\mathrm{TP}=$ the total Processing Cost excluding the Point

$\mathrm{NL}=$ New Loan Amount

$\mathrm{a}=$ The point $(\%)$
$\mathrm{NL}=(\mathrm{CLB}+\mathrm{TP})+(\mathrm{CLB}+\mathrm{TP}) \mathrm{a}+(\mathrm{CLB}+\mathrm{TP}) \mathrm{aa}+$ $(\mathrm{CLB}+\mathrm{TP}) \mathrm{aaa}+\ldots \ldots . .$.

$\mathrm{NL}=(\mathrm{CLB}+\mathrm{TP})\left(1+\mathrm{a}+\mathrm{a}^{2}+\mathrm{a}^{3}+\mathrm{a}^{4}+\ldots \ldots \ldots\right)$

$\mathrm{NL}=(\mathrm{CLB}+\mathrm{TP})(1 /(1-\mathrm{a}))$

Derivation of $(1 /(1-a))$

Let $\mathrm{Sn}=1+\mathrm{a}+\mathrm{a}^{2}+\mathrm{a}^{3}+\ldots \ldots \ldots \ldots+\mathrm{a}^{\mathrm{n}}$

$\mathrm{aSn}=\mathrm{a}+\mathrm{a}^{2}+\mathrm{a}^{3}+\ldots \ldots \ldots \ldots \ldots+\mathrm{a}^{\mathrm{n}+1}$

$\mathrm{Sn}-\mathrm{aSn}=1-\mathrm{a}^{\mathrm{n}+1}$

$\operatorname{Sn}(1-a)=1-a^{n+1}$

If $0<\mathrm{a}<1$ and $\mathrm{n}=\infty, \mathrm{a}^{\mathrm{n}}=0$.

Therefore, if $\mathrm{n}=\infty, \mathrm{Sn}=1 /(1-\mathrm{a})$

\section{Websites for Refinancing Decision}

1. http://www.bankrate.com/calculators/mortgages/refina nce-calculator.aspx

2. http://zwicke.nber.org/refinance/

3. http://www.decisionaide.com/mpcalculators/refinancin gonemortgage/refii.asp

\section{REFERENCES}

[1] Auster, R. (1998). Important Considerations for Homeowners: Who Refinance Home Mortgages, Real Estate Review, Fall, 67-70.

[2] Chen, A. and D. Ling. (1989). Optimal Mortgage Refinancing with Stochastic Interest Rates, Journal of the American Real Estate and Urban Economics Association, 17(3), 278-99.

[3] Folowill, R. and L. Johnson. (1989). Taxes and Mortgage Refinancing, The Appraisal Journal, 197- 206.

[4] Fortin, R. and S. Michelson. (2005). The Tax Impacts of Home Mortgage Refinancing: An Analysis and a Model, Journal of Real Estate Literature, 13: 2, 191-202.

[5] Johnson, R. and P. Randle. (2003). The Mortgage 
Refinancing Decision: Updated Spreadsheet. The $C P A$ Journal, February, 60-61.

[6] Valachi, D. (1982). Refinancing a Personal Residence, Real
Estate Review, Winter, 73-6.

[7] G-Yohannes, A. (1988). Mortgage Refinancing, The Journal of Consumer Affairs, 22(1), 85-95. 